\title{
MANAJEMEN PROGRAM DISIPLIN KEAMANAN (DISKAM) DALAM MENUMBUHKAN KARAKTER DISIPLIN PESERTA DIDIK
}

\author{
Febri Dwi Anggraeni \\ Manajemen Pendidikan Universitas Negeri Surabaya \\ febri.Anggraeni8@gmail.com
}

\begin{abstract}
This study aims to describe and to analyse 1) Diskam program planning in building character of students; 2) The implementation of diskam program in building discipline character of students; and 3) Evaluation of diskam program in developing the discipline character of students in State Junior High School 2 Taman Sidoarjo.This study used a qualitative approach with a case study method. Retrieval of data was done using interview, observation, and documentation study. The analysis of data used was using data condensation, data presentation, and data verification. The validity test of data was done using source of data triangulation, technical triangulation, and member check. The validity of data was checked through credibility test, transferability test, dependability test, and conformability test. The results of research related to diskam management programs in building the character of discipline in State Junior High School 2 Taman Sidoarjo indicated that 1) Diskam program planning includes determining the objectives to be achieved in the future by using several stages in forming diskam programs, and by analysing activities that will be carried out in forming diskam program 2) The implementation of diskam program are the formation of diskam member. The next activity is a coaching process which is carried out when members' selection is being held along with character building of the students. The way how diskam works is divided into several main tasks and their respective posts which are conducted by members based on the prescribed picket schedule; 3) The level of achievement of diskam programs in building the character of student discipline is $80 \%-85 \%$. Administrative supervision of members is conducted every semester, but indirectly supervision.
\end{abstract}

Keywords: Management, Discipline Character, Extracurricular

\begin{abstract}
Abstrak: Penelitian ini bertujuan untuk mendiskripsikan dan menganalisis tentang 1) Perencanaan program diskam dalam menumbuhkan karakter peserta didik; 2) Pelaksanaan program diskam dalam menumbuhkan karakter disiplin peserta didik; dan 3) evaluasi program diskam dalam menunmbuhkan karakter disiplin peserta didik di SMP Negeri 2 Taman Sidoarjo. Penelitian ini menggunakan pendekatan kualitatif dengan metode studi kasus. Pengambilan data menggunakan teknik wawancara, observasi dan studi dokumentasi. Analisis data yang digunakan adalah kondensasi data, penyajian data dan verifikasi data. Uji keabsahan data dilakukan dengan menggunakan triangulasi sumber data, triangulasi teknik, dan membercheck. Pengecekan keabsahan data menggunakan uji kredibilitas, uji transferabilitas, uji dependabilitas, dan uji konfirmabilitas. Hasil penelitian terkait manajemen program diskam dalam menumbuhkan karakter disiplin di SMP Negeri 2 Taman menunjukkan bahwa, 1) Perencanaan program diskam meliputi penentuan tujuan yang akan dicapai dimasa yang akan datang dengan menggunakan beberapa tahapan dalam pembentukan program diskam, dan menganalisis bentuk kegiatan yang akan dilaksanakan dalam pembentukan program diskam; 2) Pelaksanaan program diskam yakni pembentukan kepengurusan anggota diskam. Kegiatan selanjutnya adalah proses pembinaan yang dilaksanakan ketika tahapan selesksi anggota diskam dengan pembentukan karakter peserta didik. Cara kerja diskam dibagi menjadi beberapa tugas pokok dan pos masing-masing yang dilaksanakan oleh anggota diskam sesuai dengan jadwal piket yang telah ditentukan; 3) Tingkat ketercapaian program diskam dalam menumbuhkan karakter disiplin peserta didik yakni $80 \%-85 \%$. Pengawasan anggota diskam secara administratif dilakukan setiap semester, namun secara tidak langsung pengawasan.
\end{abstract}

Kata kunci: manajemen, karakter disiplin, ekstrakurikuler 
Pendidikan memiliki peranan penting dalam pembangunan kehidupan berbangsa dan bernegara karena pendidikan bertujuan untuk mencetak generasi penerus bangsa yang berkualitas. Pendidikan mempunyai makna penting dalam mencerdaskan kehidupan bangsa yang tercantum dalam Pembukaan (Undang-Undang Nomor 20 Tahun 2003 tentang Sistem Pendidikan Nasional., 2003) yang yang menyatakan bahwa Pendidikan Nasional berfungsi mengembangkan kemampuan dan membentuk watak serta peradaban bangsa yang bermartabat dalam rangka mencerdaskan kehidupan bangsa, bertujuan untuk berkembangnya potensi peserta didik agar menjadi manusia yang beriman dan bertakwa kepada Tuhan Yang Maha Esa, berakhlak mulia, sehat, berilmu cukup, kreatif, mandiri, dan menjadi warga negara yang demokratis serta bertanggung jawab. Pada Undang-Undang tersebut sudah sangat jelas bahwa pendidikan berfungsi mengembangkan potensi peserta didik dalam membentuk pribadi yang lebih baik. Pendidikan juga bertujuan untuk meningkatkan kualitas pendidikan dalam usaha menanamkan nilai-nilai karakter pada diri individu sehingga dapat dijadikan landasan dalam membentuk dan mengembangkan pendidikan karakter bangsa.

Pada Era modern yang sedang berjalan saat ini, memungkinkan terjadinya perubahan-perubahan. Kemajuan zaman tidak seharusnya selalu menimbulkan dampak negatif. Salah satu dampak negatif dari kemajuan zaman adalah menurunnya nilai-nilai karakter dari peserta didik, meningkatnya perilaku kekerasan, tawuran pelajar, penggunaan bahasa yang kasar dan kotor, rendahnya rasa hormat kepada orang tua dan guru, serta meningkatnya pengunaan obat-obatan terlarang. Melihat permasalahan yang ada saat ini maka penting adanya revolusi mental. Revolusi mental merupakan proses transformasi pembentukan karakter bangsa dan kesejahteraan bangsa. Revolusi mental dimaksudkan untuk membangun karakter bangsa yang mengacu kepada nilai-nilai luhur yang berdasarkan pancasila dan Undang-Undang 1945 . Karakter bangsa perlu ditanamkan dalam diri setiap individu karena karakter diibaratkan sebagai kemudi dalam kehidupan berbangsa dan bernegara. Walaupun begitu penting, ternyata perhatian terhadap pembangunan karakter bangsa belum terjaga dengan baik, sehingga hasilnya belum optimal. Karakter bangsa merupakan salah satu amanat pendiri negara dan telah dimulai sejak awal kemerdekaan. Dalam sebuah pidatonya, pendiri negara pernah berpesan bahwa tugas bangsa Indonesia dalam mengisi kemerdekaan adalah mengutamakan pelaksanaan nation and character building.

Pendidikan karakter di sekolah merupakan suatu upaya pembentukan karakter peserta didik melalui guru, temen sebaya, maupun lingkungan. Berbagai jenjang pendidikan diharapkan mampu menerapkan pendidikan karakter khususnya dalam menerapkan nilai-nilai pembentuk karakter seperti halya nilai disiplin disekolah. Untuk mencapai karakter yang diinginkan maka pendidikan karakter sangat berpengaruh dalam perkembangan anak dan usaha menanamkan nilai-nilai karakter pada anak. (Muchlas \& Haryanto, 2011) menjelaskan bahwa nilai-nilai pembentuk karakter berasal dari agama, pancasila, budaya, dan tujuan pendidikan Nasional. Nilai-nilai karakter tersebut adalah religius, jujur, tanggung jawab, disiplin, toleransi, kerja keras, peduli lingkungan, mandiri, demokratis, rasa ingin tahu, menghargai prestasi, gemar membaca, cinta damai, kreatif, cinta tanah air, semangat kebangsaan dan bersahabat.

Salah satu nilai pembentuk karakter adalah disiplin. Dalam lingkup sekolah nilai kedisiplinan sangat penting ditanamkan pada diri anak, karena setiap anak harus belajar mengasah kepekaannya mengenai moral yang dimilikinya dalam menjalani kehidupan bersama dilingkungan masyarakat. Manusia yang bermoral membutuhkan keteguhan prinsip dan kedisiplinan yang harus dimiliki sejak dini mengenai moral yang diyakini benar dan baik. Karakter disiplin bertujuan untuk menciptakan kenyaman dilingkungan sekolah terutama didalam kelas. Sekolah sebagai lembaga pendidikan formal merupakan komponen yang sangat penting dalam mengembangkan sikap disiplin peserta didik. Oleh sebab itu sekolah merupakan sebuah organisasi yang membutuhkan sebuah pengelolaan. 
Pengelolaan ini dibutuhkan dalam usaha mencapai tujuan dari pendidikan yaitu terjadinya proses belajar mengajar yang aman, tertib dan teratur sehingga hal tersebut mampu mempengaruhi peserta didik dalam menegakkan kedisiplinan di sekolah.

(Najmuddin, 2015) berpendapat bahwa disiplin ditunjukkan pada kepatuhan atau ketaatan seseorang terhadap norma-norma atau aturan-aturan yang berlaku dalam kehidupan kelompok (masyarakat). Perilaku disiplin dipengaruhi oleh berbagai faktor, yakni faktor lingkungan, keluarga dan sekolah. Tidak dapat dipungkiri bahwa sekolah merupakan salah satu faktor dominan dalam memberntuk dan mempengaruhi perikaku peserta didik, tidak hanya itu saja lingkungan juga sangat berpengaruh terhadap perilakupeserta didik. Kedisiplinan merupakan salah satu usaha sekolah untuk memelihara perilaku peserta didik agar tidak menyimpang dan dapat mendorong peserta didik untuk berperilaku sesuai norma, peraturan, dan tata tertib yang berlaku.

Rendahnya karakter disiplin dapat menimbulkan perilaku negatif pada peserta didik sehingga memicu terjadinya berbagai pelanggaran didalam sekolah. Komisi Perlindungan Anak Indonesia atau KPAI mencatat kasus tawuran di Indonesia meningkat 1,1 persen sepanjang 2018. Komisioner Bidang Pendidikan KPAI Retno Listiyarti mengatakan, pada tahun lalu, angka kasus tawuran hanya 12,9 persen, tapi tahun ini menjadi 14 persen. Berdasarkan data KPAI, 40 persen siswa usia 13-15 tahun melaporkan pernah mengalami kekerasan fisik oleh teman sebaya sedangakan 75 persesn siswa mengaku pernah melakukan kekerasan disekolah (Tempo.co, 2018). Hal yang sama terjadi di Surabaya, satpol PP melakukan razia pada tanggal 26/1/2018 dan menemukan 31 pelajar tengah membolos (Tribun.News). Hal ini menunjukkan bahwa kedisiplinan peserta didik mulai menurun dan menimbulkan dampak negatif. Oleh sebab itu perlunya pembentukan karakter peserta didik agar tujuan pendidikan .

Segala bentuk penyimpangan dapat kita hindari dengan cara memberikan sanksi yang tegas, hukuman yang tepat setara dengan bentuk penyimpangan yang dilakukan.peserta didik senantiasa ditanamkan nilai-nilai kedisiplinan dalam proses belajar mengajar baik secara akademik maupun non akademik, hal tersebut bertujuan untuk meningkatkan kedisiplinan peserta didik. Adanya pelanggaran disiplin yang banyak dilakukan peserta didik menuntut sekolah untuk bertindak cepat dan tepat. Selain memberikan didikan khusus bagi yang melanggar peraturan pihak sekolah juga berusaha untuk mengantipasi pelanggaran agar tidak terulang kembali.

Berdasarkan visi dari SMP Negeri 2 Taman Kabupaten Sidoarjo, yaitu: "Berprestasi, santun, dan kreatif dilandasi imtaq". Dalam visi tersebut terdapat kata santun dimana dalam pelaksanaan misi dilakukan melalui program DISKAM (Disiplin Keamanan). Diskam merupakan sebuah kegiatan peserta didik yang dibentuk untuk meningkatkan disiplin peserta didik di SMP Negeri 2 Taman. Diskam merupakan salah satu fungsi yang berhubungan langsung dengan peserta didik serta melaksanakan pembinaan dan pelatihan yang meliputi kegiatan mendisiplinkan, mengamankan, serta mentertibkan peserta didik di sekolah. Berdasarkan studi pendahuluan yang sudah dilakukan oleh peneliti, Kak Amran selaku pembina Diskam di SMP Negeri 2 Taman Kabupaten Sidoarjo menyampaikan Diskam terbentuk dan disahkan pada tanggal 4 April tahun 2011 dan pada tahun 2012 sudah mulai dikenal oleh masyarakat luar".

Diskam ini dapat dikatakan sebagai pasukan tim khusus SMP Negeri 2 Taman Kabupaten Sidoarjo dalam usaha meningkatkan kedisiplinan peserta didik. Diskam ini diikuti oleh peserta didik yang telah diseleksi setiap angkatan, dari kelas tujuh hingga kelas sembilan. Peserta didik yang tergabung dalam diskam ini mendapat pembinaan dan pembekalan langsung dari Polresta sidoarjo hingga tenaga kesehatan. Diskam mendapat kepercayaan dari pihak Polsek Taman untuk mengikuti kegiatan yang diadakan oleh Polresta Sidoarjo dan mendapat juara 1 lomba Think Safety pada tahun $2012 \quad$ (WWCR/SMPN 2 TAMAN/22/10/2018).

Diskam merupakan sebuah kegiatan ekstrakulikuler sekolah dimana pelaksanaannya dilakukan diluar jam 
pelajaran. Untuk menjadi anggota diskam ini peserta didik harus mengikuti tahap seleksi yang terdiri dari 13 tahapan. Dalam tahap seleksi peserta didik dibekali kemampuan sehingga mampu menjalankan tugasnya dengan baik. Diskam ini memperoleh pembekalan langsung serta adanya pengawasan yang dilakukan selama tiga bulan sekali oleh Polresta Sidoarjo. Terdapat beberapa kegiatan yang dilakukan oleh diskam, diantaranya adalah Gatur lantas, Think Safety, Baris-berbaris dan sebagainya.

Diskam di SMP Negeri 2 Taman Sidoarjo ini juga unggul dalam prestasi diantaranya adalah juara 1 lomba gatur lantas, juara 1 think safety, lomba barisberbaris setiap tahunnya, dan pada tanggal 27 Oktober 2018 diskam menjuari lomba baris-berbaris se-Jawa Timur. Penerapan program ini yaitu dilaksanakan setiap hari dimulai dengan apel pagi pada pukul 05.30 WIB kemudian melaksanakan tugas sesuai dengan jadwal yang telah ditentukan. Melalui anggota diskam ini peserta didik dituntut untuk disiplin dengan menciptakan kebiasaan-kebiasaan positif peserta didik baik dari cara berpakaian hingga sopan santun terhadap guru.

Anggota Diskam menggunakan atribut khusus yang membedakan dengan peserta didik lain, hal ini bertujuan untuk mengingatkan bahwa anggota mereka memiliki tanggung jawab khusus yakni menegakkan kedisiplinan dan keamanan sekolah dikalangan teman-temannya. Berdasarkan Standar Operasi Prosedur Pembinaan dan Penyuluhan Diskam, untuk menghapi tugas yang tidak ringan tersebut, diskam perlu mengembangkan profesionalisme dan kemampuan melihat potensi peserta didik yang dapat didayagunakan untuk bersama-sama membina kedisiplinan, keamanan serta ketertiban peserta didik. Dengan adanya petugas diskam ini harapan dari sekolah mampu membantu sekolah dalam usaha menanamkan nilai-nilai kedisiplinan dan keamanan dilingkup sekolah.

Dalam terlaksananya program agar berjalan secara efektif dan efisien tentunya dibutuhkan pengelolaan yang baik guna mencapai tujuan dari program. Program diskam ini membutuhkan pengelolaan yang dimulai dari perencanaan, implementasi, hingga evaluasi. Program diskam ini dapat menjadi ciri khas sekolah, karena tidak semua sekolah memiliki tim khusus kedisiplinan. Program ini dibentuk atas inisiatif sekolah. Sekolah senantiasa mengupayakan yang terbaik dalam pengelolaannya dan terus mengoptimalkan peran peserta didik yang ikut dalam mengikuti program ini. Berdasarkan latar belakang diatas, peneliti tertarik untuk meniliti Manajemen Program Diskam di SMP Negeri 2 Taman Kabupaten Sidoarjo. Oleh sebab itu peneliti mengambil judul " Manajemen Program Diskam dalam Menumbuhkan Karakter Disiplin Peserta Didik di SMP Negeri 2 Taman Kabupaten Sidoarjo".

\section{METODE}

Penelitian ini menggunakan pendekatan kualitatif dengan rancangan penelitian Studi Kasus. Alasan peneliti menggunakan rancangan studi kasus karena dengan menggunakan pendekatan studi kasus peneliti dapat melakukan penelitian yang mendalam untuk mengungkap fenomena dan menganalisis tentang manajemen program diskam dalam menumbuhkan karakter disiplin peserta didik di SMP Negeri 2 Taman Sidaorjo. Penelitian ini bertujuan untuk memahami fenomena yang mencakup perencaan, pelaksanaan dan evaluasi program diskam di SMP Negeri 2 Taman Sidoarjo secara holistik dan dengan cara diskripsi pada konteks khusus dengan memanfaatkan metode ilmiah.

Penelitian ini dilakukan di SMP Negeri 2 Taman Kabupaten Sidoarjo yang terletak di JL. Sawunggaling No.4 Jemundo, Taman Kabupaten Sidoarjo, Jawa Timur. Teknik pengumpulan data menggunakan wawancara, observasi, dan dokumentasi. Penelitian ini menggunakan wawancara semi terstruktur, Informan dalam penelitian ini antara lain : Kepala Sekolah SMP Negeri 2 Taman Sidoarjo, Waka Kesiswaan, Guru Bimbingan dan Konseling, Guru lainnya, Peserta didik anggota diskam, dan peserta didik non anggota diskam.

Penelitian ini menggunakan observasi non partisipan, dokumen-dokumen yang dijadikan sumber data dalam penelitian. Sumber data secara garis besar yaitu data primer dan sekunder. Teknik analisis data dalam penelitian ini meliputi kondensasi data, penyajian data, dan verifikasi data. Uji 
keabsahan data dilakukan melalui uji kredibilitas yang meliputi triangulasi sumber, triangulasi teknik, triangulasi waktu, dan membercheck; uji transferabilitas, uji dependabilitas, dan uji konfirmabilitas.

\section{HASIL DAN PEMBAHASAN \\ Perencanaan Program Diskam dalam Menumbuhkan Karakter Disiplin Peserta Didik di SMP Negeri 2 Taman Sidoarjo}

Program diskam merupakan program disiplin keamanan di SMP Negeri 2 Taman Sidoarjo mulai diterapkan pada bulan april tahun 2011. Diskam merupakan salah satu fungsi yang berhubungan langsung dengan peserta didik dalam melaksanakan tugas dan tanggung jawabnya. Secara umum program ini dibentuk untuk meningkatkan kedisiplinan peserta didik di SMP Negeri 2 Taman Sidoarjo.

Berdasarkan hasil penelitian latar belakang terbentuknya diskam adalah dikarenakan tingkat kedisiplinan peserta didik di SMP Negeri 2 Taman rendah dan lokasi sekolah terletak pada daerah jalur industri, maka untuk mengatasi hal tersebut sekolah membentuk suatu organisasi disiplinan dan keamanan sekolah di SMP Negeri 2 Taman. Program diskam merupakan kegiatan yang melibatkan peserta didik dengan menerapkan aturan guna meningkatkan kedisplinan peserta didik di SMP Negeri 2 Taman Sidoarjo. Program diskam di SMP Negeri 2 Taman ini senada dengan pendapat (Sautter, 1994) bahwa kurikulum tersembunyi merupakan kegiatan yang ditujukan kepada peserta didik dengan menerapkan kebiasaan atau berbagai aturan dalam meningkatkan kedisiplinan.

Penyelenggaraan suatu program tidak lepas dari peran manajemen didalamnya guna tercapainya tujuan dari program, sama halnya dengan program diskam yang membutuhkan peran manajemen dalam melaksanakan semua kegiatannya. Pengelolaan program diskam di SMP Negeri 2 Taman Sidaorjo berdasarkan fungsi manajemen yakni perencanaan, pengorganisasian, pelaksasanaan, pengawasan/evaluasi. Pengelolaan program diskam di SMP Negeri 2 Taman sejalan dengan pendapat (G. R. Terry, 1972) yang menjelaskan bahwa manajemen merupakan proses yang khas yang terdiri dari perencanaan, pengorganisasian, pelaksanaan, dan pengontrolan.

Dalam merumuskan program diskam, perlu adanya sebuah perencanaan agar program dapat terlaksana sesuai dengan yang diharapkan. Dalam perencanaan program diskam hal yang pertama dilakukan adalah menetapkan tujuan. Perencanaan program diskam di SMP Negeri 2 Taman ini mengacu pada pendapat (Simamora, 2004) bahwa perencanaan merupakan proses untuk menetapkan tujuan apa yang akan diraih selama periode waktu kedepan dan apa yang akan dilakukan untuk mencapai tujuan. Berdasarkan hasil penelitian tujuan terbentuknya program diskam yaitu untuk menamkan karakter disiplin kepada peserta didik dan meningkatkan keamanan di lingkungan SMP Negeri 2 Taman Kabupaten Sidoarjo.

Tujuan jangka panjang mengenai program diskam ini adalah dengan adanya program diskam diharapkan sekolah dapat melahirkan generasi yang tangguh dibidang mental spiritual dan pembentukan karakter anak melalui pembiasaan. Mencerminkan karakter/ pribadi yang paripurna dengan berpengang kepada empat pilar yakni: pancasila, UUD 1945, Bhineka Tunggal Ika, dan cinta NKRI. Dalam perencanaan program diskam ini terdapat beberapa pihak yang terlibat, diantaranya adalah Kepala Sekolah, Waka Kesiswaan, Guru, dan pembina diskam.

Diskam merupakan organisasi yang termasuk dalam ekstrakurikuler paskibra. Dimana kegiatan ekstrakurikuler tersebut merupakan rangkaian kegiatan guna mencapai tujuan pendidikan dan membentuk watak peserta didik yang dalam proses penerimaan anggotanya berdasarkan bakat dan minat peserta didik. Program diskam di SMP Negeri 2 Taman ini mengacu pada pendapat (At-Taubany \& Suseno, 2017) bahwa pengembangan kegiatan ekstrakurikuler pilihan di satuan pendidikan dapat dilakukan melalui beberapa tahapan, salah satunya adalah identifikasi kebutuhan, potensi dan minat peserta didik.

Secara khusus, berdasarkan hasil penelitian untuk menjadi anggota diskam, maka anggota paskib harus mengikuti beberapa tahapan yang terdiri dari tiga belas tahapan yang dimulai dari kegiatan pengenalan organisasi, wajib mengafal 12 
peraturan lalu lintas, penjelasan mengenai tugas dan tanggung jawab yang harus dijalankan, pembentukan karakter dan kepribadian anggota, loyalitas, kemudian di akhiri dengan diklat. Diklat yang dilaksanakan terdiri dari beberapa kegiatan yang bertujuan untuk membentuk kepribadian, mental, dan leadersihip. Perencanaan perekrutan anggota diskam di SMP Negeri 2 Taman ini sejalan dengan pendapat (Rustiadi, 1998) yang mengatakan bahwa perencanaan adalah proses menentukan apa yang ingin dicapai dimasa yang akan datang serta menetapkan tahaptahap yang dibutuhkan untuk mencapainya. Tahapan-tahapan diatas merupakan salah satu langkah awal dalam pembentukan anggota diskam. Sehingga hasil akhir dari tahapan-tahapan seleksi akan menghasilkan peserta didik yang siap secara lahir dan batin menjalankan tugas dan tanggung jawabnya sebagai anggota diskam.

Apabila dikaitkan dengan pendapat (Lickona, 1992) bahwa karakter seseorang akan terbentuk melalui tiga bagian yakni moral knowing (pengetahuan tentang moral), moral feeling (perasaan tentang mental), moral action (perbuatan moral), maka ketiga bagian tersebut saling terkait satu sama lain dalam membentuk kematangan moral. Karakter individu dapat terbentuk melalui kebiasaan-kebiasaan yang dilakukan oleh individu baik dalam pikiran, hati, dan tindakan.

Moral knowing atau pengetahuan tentang moral merupakan hal yang penting untuk diajarkan pada setiap individu, moral knowing terdiri dari eman hal yakni: 1) moral awereness (kesadaan moral); 2) knowing moral values (mengetahui nilai-nilai moral); 3) perspective-taking; 4) moral reasoning; 5) desicion making; 4) self-knowledge. Pengetahuan tentang moral ini dilakukan dengan cara memberikan pengetahuan mengenai nilai-nilai yang berlaku di masyarakat dan memberikan pengetahuan mengenai moral yang baik yang harus diterapkan dalam kehidupan sehari-hari dilakukan ketika anggota diskam berada pada tahapan seleksi yakni pada tahapan pertama peserta didik diberikan pengetahuan mengenai arti tanggung jawab. Kemudian pada tahapan-tahapan berikutnya anggota diskam diberikan materi mengenai pengembangan diri, pembentukan kepribadian peserta didik, dan anggota diskam diberikan pengetahuan mengenai cara bersikap dan berperilaku yang baik dalam kehidupan sehari-hari dilakukan dengan memberikan pengajaran secara langsung dilapangan.

Moral Feeling atau perasaan tentang mental merupakan aspek lain yang perlu ditanamkan dalam pada diri setiap individu dalam bertindak sesuai dengan nilai-nilai luhur. Terdapat enam aspek yang harus mampu dirasakan oleh seseorang untuk menjadi individu yang berkarakter, yaitu: 1) conscience (nurani); 2) self-esteem (percaya diri); 3) emphaty (merasakan penderitaan orang lain); 4) loving the good (mencintai kebenaran); 5) self control (mampu mengontrol diri); 6) humility (kerendahan hati). Berdasarkan hasil penelitian di SMP Negeri 2 Taman Moral Feeling dilakukan dengan cara menumbuhkan rasa percaya diri, empati, mampu mengotrol diri yang dilaksanakan ketika anggota diskam berada pada tahahapan seleksi.

Tahapan pertama hingga tahapan akhir merupakan salah satu upaya dalam menumbuhkan rasa percaya diri peserta didik dimana peserta didik di berikan rangsangan untuk mampu menyuarakan pendapatnya. Dalam tahapan seleksi anggota diskam juga dilatih untuk mampu mengontrol diri dimana mereka harus bersentuhan langsung dengan peserta didik lain yang memiliki karakter berbeda-beda, sehingga pembina memberikan pengajaran mengenai bagaimana cara menindak teman sebaya dan mengotrol diri sehingga sebelum mereka menindak teman sebaya mereka harus intropeksi diri terlebih dahulu menganai kedisiplinan mereka sendiri.

Moral action atau perbuatan moral merupakan bagian dari pembentukan karakter individu melalui pengetahuan moral. Pengetahuan moral dapat diwujudkan menjadi sebuah tindakan nyata. Tindakan ini merupakan outcome dari dua komponen pembentukan karakter lainya. Terdapat tiga aspek yang mendorong individu untuk mampu berperilaku baik, yakni: 1) competence (kompetensi); 2) will (keinginan); 3) habit (kebiasaan). Dalam penelitian ini Moral action yakni outcome dari komponen pembentukan karakter, yakni peserta didik memiliki kompetensi berupa kedisiplinan yang tinggi dan kompetensi lain 
yang mampu memberikan dampak positif bagi lingkungan sekitarnya contohnya anggota diskam mampu menghasilkan prestasi yang baik hingga tingkat provinsi. Keinginan yang tinggi anggota diskam dalam mewujudkan tujuan terbentuknya program diskam ini terlihat dari cara kerja mereka yang nyata dan konsisten dalam menjalankan tugas serta tanggung jawab yang telah diberikan. Seluruh kegiatan yang dilakukan menghasilkan sebuah pembiasaan dimana peserta didik anggota diskam maupun non anggota diskam menghasilkan sebuah pembiasaan. Wujud dari pembiasaan tersebut yakni kegiatan yang dilaksanakan oleh anggota diskam dari apel hingga jadwal keliling sekolah dilaksanakan secara konsisten setiap hari.

Setiap program tentunya memiliki ciri khas dan keunggulan masing-masing, sama hal nya dengan program diskam. Berdasarkan hasil penelitian yang diperoleh dilapangan, yang menjadi keunggulan dari program diskam ini adalah prestasi yang dicapai oleh diskam cukup bagus. Anggota diskam sering menjuarai perlombaan baik PBB ataupun Lantas hingga tingkat provinsi, selain itu pembentukan karakter disiplin dan kinerja anggota diskam yang bagus sehingga diskam merupakan icon SMP Negeri 2 Taman Sidoarjo.

Berdasarkan temuan data tersebut dan keseuaian antara temuan dan teori dari beberapa ahli maka dapat disimpulkan bahwa tujuan dari adanya program diskam ini adalah untuk memberikan pembelajaran kepada peserta didik dan menigkatkan kedisiplinan peserta didik di SMP Negeri 2 Taamn Sidoarjo. Tujuan jangka panjang dengan adanya diskam diharapkan sekolah mampu melahirkan generasi-generasi yang tangguh secara mental dan pembentukan karakter. Untuk menjadi anggota diskam, peserta didik harus mengikuti beberapa tahapan seleksi yang terdiri dari tiga belas tahapan seleksi. tahapan tersebut diantaranya adalah Pengenalan organisasi dan pemahaman arti tanggung jawab, Menghafal 12 peraturan lalu lintas dan Gatur Lantas, Pembagian kelompok dan penyelesaian masalah, Wajib Apel dan Jaga, Belajar tentang menindak teman sebaya, kelengkapan atribut, Pembentukan kepengurusan setiap angkatan dan membuat program kerja, Kepribadian dan
Intelektual, pengembangan diri dan kepribadian, sikap dan perilaku, peserta didik dapat mengambil sebuah keputusan dan aturan, loyalitas, Diklat Anggota diskam.

Kegiatan diskam yang dilaksanakan melalui beberapa tahapan tersebut mengajarkan bagaiaman cara bersikap yang baik dan benar, memberikan pemahaman mengenai moral, melatih mental yang bertujuan untuk pembentukan karakter peserta didik. Perencanaan program diskam di SMP Negeri 2 Taman ini sejalan dengan penelitian (Syam, 2015) yang mengangkat tema Manajemen Kedisiplinan Santri di Pondok Pesantren bahwa dalam pengelolaannya membutuhkan perencanaan didalamnya. Perencanaan pendidikan meliputi penetapan tujuan dan pembuatan jadwal kedisiplinan.

\section{Pelaksanaan Program Diskam dalam Menumbuhkan Karakter Disiplin Peserta Didik di SMP Negeri 2 Taman Sidoarjo}

Pelaksanaan program diskam dalam menumbuhkan karakter disiplin peserta didik dilaksanakan berdasarkan perencanaan yang telah ditetapkan. Apabila dikaitkan dengan pendapat (Arikunto, 2000) bahwa pelaksanaan mengandung empat jenis fungsi yakni, pengorganisasian, pengarahan, pengkoordinasian dan pengkomunikasian maka dalam penelitian ini diskam membentuk sebuah kepengurusan yang melibatkan beberapa komponen, yakni: Kepala sekolah, Wakil Kepala Sekolah bagian kesiswaan, Pembina/Pelatih diskam, dan anggota diskam yang terbagi menjadi beberapa bagian inti yaitu pemangku adat, dansat, wadansat, komisi disiplin, asisten operasional, dan biro-biro lainnya. Setiap bagian memiliki kewajiban yang harus dijalankan tanpa pengecualian agar tujuan program diskam berjalan secara efektif dan efisien. Struktur kepengurusan anggota diskam di SMP Negeri 2 Taman mengacu pada pendapat (Yahya, 2006) bahwa pengorganisasian merupakan suatu proses untuk merancang struktur formal mengelompokkan dan mengatur serta membagi tugas atau pekerjaan diantara para anggota organisasi agar tujuan organisasi dapat dicapai dengan efisien.

Pelaksanaan program diskam ini didukung dengan adanya pergerakan dari pimpinan yang menimbulkan kerja sama dan 
kerja keras dari setiap komponen yang terlibat dalam program diskam sehingga program berjalan sesuai dengan tujuan. Berdasarkan hasil penelitian menunjukkan bahwa pelatih diskam bekerja sama dengan komandan diskam dalam menggerakkan dan mengkoordinir anggotanya untuk melaksanakan tugas yang diberikan dengan aktif dalam segala kegiatan seperti jadwal jaga, pembuatan mading dan melatih anggota untuk senantiasa bekerja sama dalam mencapai tujuan. Pelaksanaan program diskam di SMP Negeri 2 Taman ini sependapat dengan (Terry, G. R, dan Heslie, 1993) bahwa pelaksanaan merupakan usaha menggerakkan anggota-anggota kelompok sedemikian rupa, hingga mereka berkeinginan dan berusaha untuk mencapai tujuan yang telah direncanakan.

Berdasarkan temuan data dilapangan, seluruh kegiatan diskam dilakukan diluar jam pembelajaran yakni dimulai pada pagi hari pada jam ke enol atau jam 05.50 WIB hingga masuk kelas yakni menjaga do'a. Dan kegiatan lainnya dilaksanakan ketika sepulang sekolah sehingga tidak mengganggu proses pembelajaran. Kegiatan diskam di SMP Negeri 2 Taman ini sesuai dengan Permendikbud Nomor 81A Tahun 2013, yang menyatakan bahwa pengembangan potensi peserta didik dapat diwujudkan melalui kegiatan ekstrakurikuler yang merupakan salah satu kegiatan dalam program kurikuler. Kegiatan ekstrakurikuler tersebut adalah program kurikuler yang alokasi waktunya tidak ditetapkan dalam kurikulum. Kegiatan ekstrakurikuler merupakan suatu program di luar jam pelajaran sekolah yang dilakukan dalam rangka pencapaian tujuan pendidikan dan berupaya membentuk watak dan kepribadian serta pengembangan bakat, minat, dan keunikan peserta didik.

Pembentukan karakter disiplin peserta didik di SMP Negeri 2 Taman dilaksanakan untuk terwujudnya tujuan program diskam. Apabila dikaitkan dengan pendapat (Sudjana, 2004) bahwa pengarahan atau pembinaan dapat diartikan sebagai upaya memelihara atau membawa suatu keadaan yang seharusnya terjadi atau menjaga keadaan sebagaimana sejarusnya terlaksana. Maka berdasarkan temuan data di SMP Negeri 2 Taman ini sistem pembinaan diskam identik dengan pembentukan karakter peserta didik utamanya disiplin, tanggung jawab, sikap, kejujuran, dan pengambilan keputusan. Pembinaan tersebut dilaksanakan ketika peserta didik melalaui tahapan seleksi. Pada tahapan seleksi tersebut peserta didik akan dibina dan menanamkan karakter disiplin dan tanggung jawab. Pembinaan tersebut juga dilakukan untuk membentuk sikap dan kejujuran peserta didik, dimana cara bersikap yang baik dan benar sangat dibutuhkan.

Berdasarkan hasil penelitian dilapangan latihan program diskam dilaksanakan pada hari senin dan kamis sepulang sekolah tepatnya pada pukul 14.30 WIB s.d 16.00 WIB. Bentuk latihan yang dilaksanakan adalah sikap yang diaplikasikan dalam gerakan PBB. Bentuk latihan yang kedua yakni lantas dilaksanakan pada hari jum'at pukul 06.00 WIB, kegiatan tersebut berupa senam gatur lantas, gatur berjalan dan 12 pengaturan lalu lintas. Cara kerja diskam dimulai dengan Apel yang dilaksanakan pada pukul 05.50 WIB kemudian dilanjutkan dengan bertugas sesuai dengan posnya masing-masing.

Dalam pembentukan karakter disiplin peserta didik, anggota diskam bertugas mengawasi teman-teman yang tidak taat peraturan utamanya dalam kelengkapan berpaikan. Seluruh peserta didik harus mentaati peraturan yang ada di SMP Negeri 2 Taman Sidoarjo. Tugas yang dijalankan oleh diskam dalam mendisiplinkan peserta didik di SMP Negeri 2 Taman ini senada dengan pendapat (Tu'u, 2004) bahwa disiplin adalah sebuah upaya untuk mengikuti dan mentaati peraturan, nilai, dan hukum yang berlaku, yang muncul karena adanya kesadaran diri bahwa ketaatan itu berguna bagi kebaikan dan keberhasilan dirinya.

Rutinitas harian yang dilakukan oleh anggota diskam yakni, 1) Apel pagi; 2) lantas; 3) ketertiban; 4) jaga doa; 5) bersih joglo; 6) piket ruang RP; 7) senam; 8) jualan. Sekolah membentuk suatu kegiatan yang dilaksanakan secara terus menerus sehingga menghasilkan sebuah rutinitas yang bersentuhan langsung dengan peserta didik dilingkungan sekolah. Program kerja anggota diskam di SMP Negeri 2 Taman sejalan dengan pendapat (Apple, 1979) yang mendefinisikan kurikulum tersembunyi 
sebagai pengajaran yang dilakukan tersamar kepada siswa dari norma, nilai, dan disposisi yang berlangsung disekolah dan bagaimana cara mengatasinya dengan harapan dapat menciptakan suatu rutinitas atau kebiasaan sekolah untuk beberapa tahun kedepan. Hal ini bertujuan untuk mengembangkan potensi peserta didik sesuai dengan kebutuhannya.

Peraturan yang diberikan sekolah untuk diskam yakni hanya mengingatkan temannya yang tidak taat peraturan. Segala bentuk peraturan peserta didik tertuang dalam buku pribadi peserta didik yang dimiliki oleh seluruh peserta didik. Buku ini sebagai penghubung antara sekolah dan orangtua. Segala bentuk peraturan terdapat dalam buku pribadi peserta didik yang disertai dengan poin-poin pelanggaran. Peserta didik yang melanggar peraturan akan dikenai hukuman sesuai dengan jenis pelanggaran. Dalam buku peserta didik juga terdapat reward atau penghargaan bagi siswa yang berprestasi. Hasil penelitian di SMP Negeri 2 Taman ini mendukung pendapat (Hurlock, 1990)yang menjelaskan bahwa disiplin diharapkan mampu mendidik anak untuk berperilaku sesuai dengan peraturan atau tata tertib yang ditetapkan oleh kelompok sosial tertentu, sehingga dalam setiap kelompok sosial harus memiliki empat unsur pokok disiplin, yaitu peraturan, hukuman, penghargaan, dan konsistensi.

Berdasarkan hasil temuan data dan kesesuaian antara data dengan teori, pelaksanaan program diskam berjalan dengan baik. Pelaksanaan program diskam dimulai dengan pengorganisasian dengan cara membentuk struktur formal yang didalamnya terdiri dari beberapa bagian dengan tanggung jawab masing-masing. jadwal pembinaan anggota diskam dilaksanakan ketika peserta didik memasuki tahapan seleksi yang berupa penanaman karakter. Sedangkan pelatihan dilaksanakan berdasarkan jadwal yang telah ditentukan bersama yakni pada hari senin dan kamis. Cara kerja diskam dan progja diskam dilaksanakan diluar jam pembelajaran yakni dimulai pukul 05.50 hingga jam masuk kelas kemudian dilanjutkan lagi setelah pulang sekolah. upaya mendisiplinkan peserta didik dilakukan dengan adanya sebuah peraturan dimana peraturan tersebut harus ditaati oleh seluruh peserta didik.
Peraturan di SMP Negeri 2 Taman Sidoarjo tertuang dalam buku Pribadi Peserta Didik, dimana di dalam buku tersebut pelanggaran dan juga reward yang berikan kepada peserta didik yang berprestasi. Pendapat yang sama disampaikan (Maulidiyah, 2014) dalam penelitiannya yang mengangkat teman Manajemen Ekstrakurikuler dalam mengembangkan sekolah berwawasan lingkungan. Dalam pelaksanaan program ekstrakurikuler dimulai dari kegiatan penjadwalan hingga pelaksanaan kegiatan.

\section{Evaluasi Program Diskam dalam Menumbuhkan Karakter Disiplin Peserta Didik di SMP Negeri 2 Taman Sidoarjo.}

Evaluasi merupakan suatu proses atau tindakan untuk menentukan nilai tertentu terhadap sesuatu. Evaluasi ini sangat penting dilakukan karena dapat mengetahui tingkat keberhasilan suatu program. Sama halnya dengan program diskam, secara administratif berdasarkan data peneliti dilapangan supervisi diskam merupakan bentuk pengawasan dari sekolah yang dilaksanakan setiap semester, yakni pada bulan Maret dan November. Dari kegiatan supervisi akan menghasilkan sebuah pencatatan yang kemudian akan di evaluasi. Namun secara tidak administratif pengawasan diskam dilakukan setiap hari oleh pembina dan waka kesiswaan. Pengawasan program diskam di SMP Negeri 2 Taman ini sejalan dengan pendapat (George R Terry, 2006) yang mengemukakan bahwa pengawasan adalah mendeterminasi apa yang telah dilaksanakan, artinya mengevaluasi prestasi kerja dan apabila perlu menerapkan tindakan-tindakan korektif sehingga hasil pekerjaan sesuai dengan rencana yang telah ditetapkan.

Evaluasi anggota diskam dilaksanakan setiap satu tahun bersama pembina diskam berupa evaluasi hasil kinerja dan pencapaian program diskam. Menganalisis kekurangan atau masalah yang dihadapi selama satu periode. Berdasarkan data dilapangan tidak hanya rapat tahunan, diskam juga mengadakan rapat bulanan yang berkaitan dengan koordinasi kinerja saat bertugas. Evaluasi ini dilaksanakan dalam bentuk rapat yang dipimpin oleh Komandan Satuan diskam dan didampingi 
oleh pembina. Evaluasi program diskam di SMP Negeri 2 Tama ini senada dengan pendapat yang dikemukakan oleh Arikunto (2009: 290) bahwa evaluasi program adalah suatu rangkaian kegiatan yang dilakukan dengan sengaja untuk melihat tingkat keberhasilan program.

Berdasarkan hasil penelitian dilapangan, adanya diskam ini memberikan dampak yang baik dalam pembentukan karakter peserta didik. Peserta didik mengalami perubahan pada diri mereka sendiri. Tidak hanya karakter disiplin, peserta didik cenderung memiliki sopan santun dan manajemen waktu yang cukup baik. Karena mereka harus mampu mengimbangi antara diskam dan pembelajaran. Apabila dikaitkan pendapat (Budiarti, 2014) bahwa indikator kedisiplinan peserta didik yakni, masuk sekolah tepat waktu, kelengkapan berpakaian, melaksanakan kegiatan ekstrakurikuler yang dilaksanakan sekolah, dan melaksanakan seluruh kegiatan belajar secara aktif, maka tingkat ketercapaian program diskam dalam menumbuhkan karakter disiplin peserta didik di SMP Negeri 2 Taman ini mencapai $80 \%-85 \%$. Evaluasi program diskam di SMP Negeri 2 Taman ini mengacu pada pendapat Arikunto (2009: 290) bahwa melakukan evaluasi program adalah kegiatan yang dimaksudkan untuk mengetahui seberapa tinggi tingkat keberhasilan dari kegiatan yang direncanakan.

Apabila dikaitkan dengan pendapat (AtTaubany \& Suseno, 2017) Sistematika program kegiatan ekstrakurikuler sekurangkurangnya memuat tentang: 1) rasional dan tujuan umum; 2) deskripsi setiap kegiatan ekstrakurikuler; 3) pengelolaan; 4) pendanaan; 5) evaluasi, maka berdasarkan data peneliti di SMP Negeri 2 Taman ini yang menjadi hambatan dalam berlangsungnya program diskam adalah sekolah tidak memiliki pendaan khusus anggota diskam. Namun anggota diskam mampu mengatasi hambatan tersebut dengan adanya kas diskam sebesar dua ribu rupiah yang dilakukan setiap hari senin hingga kamis. Dana tersebut dipergunakan sebaik mungkin untuk kelancaran seluruh kegiatan diskam. Seluruh kegiatan perlombaan yang diikuti oleh anggota diskam berasal dari dana yang mereka kumpulkan melalui kas pribadi. Hambatan dalam berlangsungnya program ini juga mendukung pendapat (Matnuh, Yanti, \& Adawiah, 2016) bahwa tidak semua kegiatan dapat berjalan dengan lancar, tetapi juga mengalami kendala-kendala. Kendala yang ada tidak terjadi pada semua kegiatan ekstrakurikuler, melainkan hanya terjadi pada sebagian kegiatan ekstrakurikuler saja.

Berdasarkan data temuan penelitian evaluasi program dilakukan untuk mengukur tingkat keberhasilan dari program diskam. Evaluasi yang dilakukan program diskam adalah dengan membentuk rapat evaluasi hasil kinerja yang diadakan setiap bulan dan pertahun. Evaluasi diskam dapat dilakukan secara mandiri ataupun oleh Lembaga. Evaluasi yang dilakukan oleh lembaga dilaksanakan setiap semester yakni bulan Maret dan November. Apabila dikaitkan dengan pendapat (Ismayaningrum, 2016) bahwa pemantauan program ekstrakurikuler dilakukan secara rutin oleh waka kesiswaan dan pembina, maka dalam penelitian ini pengawasan anggota diskam diadakan setiap hari oleh pembina dan waka kesiswaan. Dampak yang diperoleh dengan adanya program diskam adalah perubahan pada diri mereka sendiri, pembentukan karakter yang bagus dan rasa tanggung jawab yang tinggi. Evaluasi program diskam ini sejalan dengan penelitian yang dilakukan (Syam, 2015) yakni pengawasan dilakukan secara langsung dan tidak langsung.

\section{KESIMPULAN}

Berdasarkan hasil penelitian terdapat beberapa pernyataan sebagai simpulan yang dapat diuraikan sebagai berikut: 1) Pengelolaan program diskam di SMP Negeri 2 Taman Kabupaten Sidoarjo didukung dengan adanya perencanaan program yaitu penentuan tujuan yang akan dicapai dimasa yang akan datang, dengan menggunakan beberapa tahapan dalam pembentukan program diskam, dan menganalisis bentuk kegiatan yang akan dilaksanakan dalam pembentukan program diskam. 2) Pelaksanaan program diskam di SMP Negeri 2 Taman Kabupaten Sidoarjo yakni pembentukan kepengurusan anggota diskam yang melibatkan beberapa komponen yakni Kepala Sekolah, Waka Kesiswaan, Pembina, dan Anggota diskam. Kegiatan selanjutnya adalah proses 
pembinaan yang dilaksanakan ketika tahapan seleski anggota diskam dengan pembentukan karakter peserta didik. Pelatihan anggota diskam dilaksanakan pada hari senin dan kamis sepulang sekolah dan pada saat senam hari Jum'at. Cara kerja diskam dibagi menjadi beberapa tugas pokok dan pos masing-masing yang dilaksanakan oleh anggota diskam sesuai dengan jadwal piket yang telah ditentukan. Peraturan yang ada didalam organisasi harus ditaati oleh anggota diskam, dan segala jenis peraturan terdapat pada buku pribadi peserta didik yang diberikan oleh sekolah. 3) Tingkat ketercapaian program diskam dalam menumbuhkan karakter disiplin peserta didik yakni $80 \%-85 \%$. Program diskam ini memberikan dampak bagi peserta didik yakni pembentukan karakter yang sangat bagus, sopan santun anggota diskam yang bagus serta peserta didik memiliki manajemen waktu yang baik. Dampak lain yang diberikan adalah peserta didik lain adalah program ini mampu berpengaruh terhadap kedisiplinan peserta didik lain. Pengawasan anggota diskam secara administratif dilakukan setiap semester, namun secara tidak langsung pengawasan dilakukan setiap hari oleh pembina dan waka kesiswaan. Evaluasi kinerja diskam dilakukan setiap tahun dan bulan melalui pengkoordinasian oleh komandan Satuan diskam.

\section{SARAN}

Berdasarkan paparan data, temuan penelitian, pembahasan, serta kesimpulan, maka peneliti mengemukakan saran-saran yang ditunjukan bagi: 1) Kepala Sekolah, pengawasan oleh kepala sekolah diperlukan dalam berjalannya program diskam, disarankan untuk kepala sekolah melakukan pengawasan secara langsung terkait berjalannya program diskam dalam menumbukan karakter disiplin peserta didik. 2) Waka Kesiswaan, terwujudnya tujuan sekolah dalam mendisiplinkan peserta didik diperlukan kerjasama antara sekolah kesiswaan dan program diskam, maka hendaknya waka kesiswaan senantiasa berkolaborasi dengan diskam dalam menumbuhkan kedisiplinan peserta didik. 3) Pembina Diskam, agar peserta didik tidak hanya memperoleh materi mengenai PBB saja, disarankan untuk pembina diskam meningkatkan materi yang diajarkan saat pelatihan. 4) Sekolah Lain, penelitian ini dapat menjadikan fungsi manajemen sebagai pengelolaan program dengan melakukan perencaan, pengorganisasian, pelaksaan dan pengawasan terkait berjalannya program. 5) Peneliti Lain, untuk peneliti lain diharapkan hasil penelitian ini dapat dijadikan sebagai bahan referensi serta informasi untuk menambah dan mengembangkan khasanah ilmu pengetahuan seputar manajemen program diskam.

\section{DAFTAR RUJUKAN}

Apple, M. W. (1979). What correspondence theories of the hidden curriculum miss. The Review of Education/ Pedagogy/ Cultural Studies. France.

Arikunto, S. (2000). Manajemen Kurikulum. Yogyakarta: FIP UNY.

Arikunto, S. (2009). Dasar-Dasar Evaluasi Pendidikan. Edisi Revisi. Jakarta: Bumi Aksara.

At-Taubany T.I \& Suseno. (2017). Desain Pengembangan Kurikulum 2013 di Madrasah. Jakarta: Kencana.

Budiarti, F. (2014). Penanaman Karakter Disiplin Dan Tanggung Jawab Melalui Kegiatan Ekstrakurikuler Patroli Keamanan Sekolah (Studi Kasus pada Kegiatan Ekstrakurikuler Patroli Keamanan Sekolah di SMK Negeri 2 Sragen Tahun Ajaran 2013/2014). Doctoral dissertation, Universitas Muhammadiyah Surakarta. (Diakses pada tanggal 30 Oktober 2018).

Henry, S. (2004). Manajemen Sumber Daya Manusia: Edisi III. Yogyakarta: STIE YKPN.

Hurlock, E. B. (1990). Perkembangan Anak. Edisi Keenam. Terjemahan Meitasari Tjandrasa. Jakarta: Erlangga.

Ismayaningrum, E. (2016). Efektivitas Pelaksanaan Kegiatan Ekstrakurikuler Kepramukaan dalam Menanamkan Pendidikan Karakter di SMK Negeri 1 Bukateja, Kecamatan Bukateja Kabupaten Purbalingga. Skripsi 


\begin{tabular}{llr} 
Sarjana & Universitas & \multicolumn{2}{r}{$\begin{array}{r}\text { Negeri } \\
\text { Yogyakarta. }\end{array}$ (Diakses } & pada 24 \\
November 2018). & &
\end{tabular}

Lickona, K. (1992). Educating for Character: How Our Schools Can Teach Rescpect and Responsibility. New York: Bantam Books.

Matnuh, H., Yanti, N., \& Adawiah, R. (2016). Pelaksanaan kegiatan ekstrakurikuler dalam rangka pengembangan nilainilai karakter siswa untuk menjadi warga negara yang baik di sma korpri banjarmasin. Jurnal Pendidikan Kewarganegaraan (diakses pada 28 November 2018).

Maulidiyah, I. (2014). Manajemen Ekstrakurikuler dalam

Mengembangkan

Sekolah

Berwawasan Lingkungan di SMA 3 Annuqayah Guluk-Guluk. Sumenep. Skripsi Sarjana Universitas Negeri Islam Maulana Malik Ibrahim Malang (diakses pada 28 November 2018).

Najmuddin. (2015). Implementasi Bimbingan Kedisiplinan Terhadap Siswa SMA Balul Maghfirah Cot Keu Ueng. Lentera, Vol. 13 No. 4. (Diakses pada tanggal 17 Oktober 2018).

Rustiadi, dkk. (1998). Perencaan dan Pengembangan Wilayah. Jakarta: Yayasan Obor Indonesia.

Samani, Muchlas, \& Hariyanto. (2011). Konsep dan Model Pendidikan Karakter. Bandung: Remaja Rosdakarya.

Sautter, C. R. (1994). An Arts Education: School Reform Strategy. Phi Delta Kappan.

Sudjana, N. (2004). Manajemen Program Pendidikan. Bandung: Falah Production.

Syam, A. R. (2015). Manajemen Pendidikan Kedisiplinan Santri di Pondok Pesantran (Studi Kasus di Pondok Pesantren Modern Darussalam Gontor Ponorogo. Skripsi Tesisi Universitas Islam Negeri Maulana Malik Ibrahim
Malang. (Diakses pada 08 November 2018).

Terry, G. R. (1972). Principles of Management. Sixth Edition. Homewood. Illinois: Richard D. Irwin. Inc.

Terry, G. R. (2006). Prinsip-Prinsip Manajemen. Jakarta: Bumi Aksara.

Terry, G. R, \& Heslie, W. R. (1993). DasarDasar Manajemen. Jakarta: Bumi Aksara.

Tu'u, T. (2004). Peran Disiplin Pada Perilaku dan Prestasi Siswa. Jakarta: Grasindo.

Undang-Undang Nomor 20 Tahun 2003 tentang Sistem Pendidikan Nasional.

Yahya, Y. (2006). Pengantar Manajemen. Yogyakarta: Graha IImu. 